\title{
SOSIALISASI DAN PELATIHAN PEMBUATAN RAPORT MENGGUNAKAN MENU MAILING PADA GURU-GURU SD TONDANO
}

\author{
Juliana M. Sumilat \\ Prodi PGSD, Fakultas Ilmu Pendidikan, UNIMA \\ julianasumilat@unima.ac.id
}

\begin{abstract}
Abstrak
Kemajuan teknologi yang begitu canggih membawa berbagai dampak dalam segala lini kehidupan, termasuk didalamnya dunia pendidikan. Berbagai kegiatan disekolah baik dalam bidang pembelajaran atau bidang administrasi makin dimudahkan oleh teknologi. Salah satu contohnya yaitu dalam pengolahan nilai dan penulisan raport dengan cara konvensional memakan waktu dua sampai tiga hari untuk penulisan raport 20 siswa, namun jika memanfaatkan teknologi pengolahan dan penulisan raport hanya akan memakan waktu satu sampai dua jam. Namun kenyataannya para guru SD di Tondano yang sementara melanjutkan studi di Prodi PGSD untuk meraih gelar S1 belum memanfaatkan kemajuan teknologi yang ada. Mereka masih menuliskan raport secara manual dikarenakan kurangnya pengetahuan tentang kemajuan teknologi dalam hal pembuatan raport. Bersamaan dengan itu kami juga dimintakan untuk mengadakan aktualisasi nilai-nilai ANEKA dari hasil Diklat Prajabatan dalam tupoksi kami salah satunya pengabdian pada masyarakat. Berdasarkan uraian diatas maka kami melakukan kegiatan pengabdian pada masyarakat dengan judul kegiatan "Sosialisasi dan Pelatihan Pembuatan Raport Dengan Mailing Pada Guru-Guru SD Tondano" Pengabdian ini dilaksankan di Laboratorium Komputer Fakultas Ilmu Pendidikan Unima pada tanggal 29 September 2016. Pelaksanaan pengabdian ini terdiri dari dua tahap yaitu pertama sosialisasi tentang kemajuan teknologi dalam bidang pendidikan. Selanjutnya tahap kedua dilanjutkan dengan pelatihan pembuatan raport. Tujuan pengabdian ini adalah memberikan pengetahuan dan pengalaman tentang kemajuan teknologi dalam bidang pendidikan khususnya dalam pembuatan raport dengan menu mailing. Hasil yang dicapai melalui kegiatan pengabdian ini adalah para guru memperoleh pengetahuan dan pengalaman tentang cara memanfaatkan teknologi dalam dunia pendidikan lebih khusus dalam pembuatan raport dengan menu mailing.
\end{abstract}

Kata Kunci: Mail Merge, Raport

\section{PENDAHULUAN}

Perkembangan Teknologi Informasi beberapa tahun belakangan ini berkembang dengan cepat. Kemajuan teknologi yang begitu canggih membawa berbagai dampak dalam segala lini kehidupan,. Pandangan masyarakat telah berubah akibat dari perkembangan teknologi dalam mencari dan mendapatkan informasi yang tidak lagi terbatas pada media masa seperti surat kabar, televisi dan radio, namun informasi dapat ditemukan melalui sumber lainnya diantaranya adalah melalui internet. Salah satu bidang yang mendapatkan dampak yang cukup berarti dengan perkembangan teknologi ini adalah bidang pendidikan. Pendidikan pada dasarnya merupakan suatu proses komunikasi dan informasi dari pendidik kepada peserta didik yang berisi informasi - informasi pendidikan, yang memiliki unsur pendidik atau guru sebagai sumber informasi, media sebagai saran penyajian ide, gagasan dan materi pendidikan, serta pendidik itu sendiri dituntut untuk memiliki berbagai macam keterampilan dan keahlian untuk menunjang tugasnya dalam melaksanakan kegiatan pembelajaran di sekolah. 
Standar kompetensi pedagogik guru sekolah dasar berdasarkan permendiknas nomor 16 tahun 2007 tentang standar kualifikasi akademik dan kompetensi guru salah satunya adalah memanfaatkan teknologi informasi dan komunikasi untuk kepentingan pembelajaran. Semua tenaga pendidikan khususnya guru diharuskan dapat menggunakan alat teknologi khususnya komputer. Hali ini tentu saja menjadi sebuah tantangan bagi guru-guru di sekolah dasar yang sudah tidak muda lagi, karena pada umumnya mereka mengalami kesulitan dalam memahami suatu hal yang masih baru dalam dunia mereka.

Berbagai kegiatan disekolah baik dalam bidang pembelajaran atau bidang administrasi makin dimudahkan oleh teknologi. Salah satu contohnya yaitu dalam pengolahan nilai dan penulisan raport dengan cara konvensional memakan waktu dua sampai tiga hari untuk penulisan raport 20 siswa, namun jika memanfaatkan teknologi yaitu aplikasi Microsoft Office dengan menu Mail Merge, pengolahan dan penulisan raport hanya akan memakan waktu satu sampai dua jam. Sehingga apa yang diharapakan boleh terselesaikan dengan waktu yang singkat dan memperoleh hasil yang maksimal.

Mail merge adalah perangkat lunak menggambarkan fungsi produksi (angka dan berpotensi besar) beberapa dokumen dari satu template yang bentuknya sama dan datanya terstruktur . Mail Merge dapat membuat data field pada surat, label dan 2 amplop terisi secara otomatis sesuai dengan record data sumbernya. Nama lain Mail merge adalah surat masal, dimana surat yang kontennya senada dan dikirimkan ke banyak orang atau tujuan yang berbedabeda. Dengan mail merge, pengiriman surat ke banyak tujuan dapat diselesaikan secara cepat dan tepat. Surat dibuat menggunakan dokumen utama dan sumber data. Dokumen utama dibuat pada satu aplikasi Microsoft Office Word dan dokumen data dibuat pada mirsoft excel. Mail Merge, dapat ditemukan pada salah jendela di aplikasi Microsoft word untuk menyatukan data base di Microsoft excel dan file master dalam bentuk surat pada Microsoft word.

Namun kenyataannya para guruguru SD di Tondano yang sementara melanjutkan studi di Program Studi PGSD untuk meraih gelar S1 belum memanfaatkan kemajuan teknologi yang ada. Mereka masih menuliskan raport secara manual dikarenakan kurangnya pengetahuan tentang kemajuan teknologi dalam hal pembuatan raport dengan menu mailing.

Bersamaan dengan itu kami juga dimintakan untuk mengadakan aktualisasi nilai-nilai Akuntabilitas, Nasionalisme, Etika Publik, Komitmen Mutu dan Anti Korupsi (ANEKA) dari hasil Diklat Prajabatan Golongan III Pola Kerjasama Kementrian Riset Teknologi Dan Pendidikan Tinggi dan Badan Diklat Sulut dalam tupoksi kami yaitu tridharma perguruan tinggi yang salah satunya pengabdian pada masyarakat. 
Berdasarkan uraian diatas maka kami melakukan kegiatan pengabdian pada masyarakat dengan judul kegiatan "Sosialisasi dan Pelatihan Pembuatan Raport Dengan Mailing Pada Guru-Guru SD Tondano"

\section{METODOLOGI PENGABDIAN}

\section{Tempat dan Waktu Pengabdian}

Pengabdian ini dilaksankan di Laboratorium Komputer Fakultas Ilmu Pendidikan Unima pada tanggal 29 September 2016.

\section{Pelaksanaan Pengabdian}

Pelaksanaan pengabdian ini terdiri dari dua tahap yaitu yang pertama sosialisasi tentang kemajuan teknologi dalam bidang pendidikan. Selanjutnya tahap kedua dilanjutkan dengan pelatihan pembuatan raport.

\section{Tujuan Pengabdian}

Tujuan pengabdian ini adalah memberikan pengetahuan dan pengalaman tentang kemajuan teknologi dalam bidang pendidikan khususnya dalam pembuatan raport dengan menu mailing.

\section{HASIL DAN PEMBAHASAN}

Pada tahapan pertama kegiatan pengabdian ini adalah guru-guru diberikan materi dan penjelasan serta contoh-contoh tentang kemajuan teknologi dalam dunia pendidikan. Setelah diberikan pemahaman, kegiatan pengabdian dilanjutkan dengan pelatihan pemanfaatan teknologi dalam dunia pendidikan khususnya pembuatan raport menggunakan menu mailing agar materi tersebut akan benar-benar menjadi pengetahuan para guru-guru dan dapat dipraktekan ketika mereka kembali ketempat tugas mereka masing-masing. Adapun materi yang diberikan dalam sosialisasi disajikan berikut ini.

\section{Rapor (Laporan Hasil Belajar Siswa)}

Belajar dan mengajar merupakan suatu proses yang mengandung tiga unsur yang dapat dibedakan, yakni tujuan pengajaran (instruksional), pengalaman (proses) belajar mengajar, dan hasil belajar (Sudjana, 2005). Ketiga unsur ini saling berkaitan, karena untuk berhasil tidaknya tujuan instruksional itu dapat dilihat dari hasil belajar siswa. Hasil belajar merupakan perubahan tingkah laku yang terjadi setelah melewati proses belajar mengajar mencakup bidang kognitif, afektif dan psikomotor.

Aspek kognitif terdiri dari 6 tingkatan berfikir yaitu:

a. Pengetahuan (knowledge), kemampuan mengingat (misalnya: rumus, ibu kota provinsi)

b. Pemahaman (comprehension), kemampuan memahami (misalnya: menyimpulkan soal cerita)

c. Aplikasi (application), kemampuan penerapan (misalnya: menggunakan suatu informasi/ pengetahuan yang diperoleh dalam penyelesaian masalah) 
d. Analisis (analysis), kemampuan menganalisis suatu informasi yang luas menjadi bagian-bagian kecil (misalnya: menganalisis bentuk, maksud suatu pantun)

e. Sintesis (synthesis), kemampuan menggabungkan beberapa informasi menjadi suatu kesimpulan (misalnya: memformulasikan hasil penelitian yang dilakukan pada lingkungan)

f. Evaluasi (evaluation), kemampuan dalam mempertimbangkan mana yang baik dan mana yang buruk dalam mengambil suatu keputusan.

Aspek afektif terdiri dari 4 tingkatan berfikir yaitu:

a. Mencakup penilaian: sikap, tingkah laku, minat, emosi dan motivasi, kerjasama, koordinasi dari setiap peserta didik.

b. Dilakukan melalui observasi langsung dan interaksi langsung secara terus menerus. Pada umumnya dilakukan secara non-ujian (misalnya: untuk mengetahui siapa peserta didik yang dapat dipercaya, siapa peserta didik yang disiplin)

c. Setiap informasi yang sudah diperoleh, dikumpulkan dan disimpan untuk bahan referensi dalam penilaian berikutnya.

d. Penilaian afektif dibagi atas penilaian afektif secara umum (budi pekerti) dan penilaian afektif per mata pelajaran.

Aspek psikomotor yang bisa juga disebut psikonigtif terdiri dari 2 tingkatan berfikir yaitu: a. Tidak semua mata pelajaran dapat dinilai aspek psikomotornya (disesuaikan dengan kompetensi dasar yang harus dicapai oleh setiap peserta didik)

b. Digunakan dalam pembelajaran yang melakukan praktik. Misalanya: pendidikan agama, pendidikan seni, pendidikan jasmani, IPA dan pelajaran bahasa.

Seorang guru dapat menentukan hasil belajar siswa dari sebuah penilaian. Penilaian dapat diartikan sebagai proses sistematis melalui pengumpulan informasi (angka, deskripsi, verbal), analisis interpretasi untuk mengambil suatu keputusan. Suryabrata mengemukakan beberapa fungsi penilaian dalam proses pendidikan, yaitu:

a. Dasar psikologis, secara psikologis, seseorang ingin untuk mengetahui sudah sampai sejauh mana ia berhasil mencapai tujuannya. Masalah kebutuhan psikologis akan pengetahuannya akan usaha yang telah dilakukannya dapat dilihat dari dua sisi, yaitu dari segi siswa dan dari segi guru. Dari segi siswa, seorang anak dalam menentukan sikap dan tingkah lakunya seringkali berpatokan pada orang dewasa. Dengan adanya pendapat guru tentang hasil belajar yang telah diperoleh maka anak merasa mempunyai pegangan, gambaran keberhasilan dan memiliki sebuah kepastian. Selain itu seorang anak juga 
butuh mengetahui statusnya jika dibandingkan dengan teman-temannya, tergolong apakah dia (apakah anak yang pandai, sedang dan sebagainya); terkadang juga dia membutuhkan untuk membandingkan dengan temantemannya dan alat yang sangat baik untuk melihat ini adalah pendapat pendidik (khususnya guru) terhadap kemajuan mereka.

Dari segi guru, seorang guru yang professional selalu ingin mengetahui hasil-hasil usahanya untuk dijadikan pedoman dalam melaksanakan usahausaha lebih lanjut.

b. Dasar didaktis, dari segi siswa, pengetahuan akan kemajuan-kemajuan yang telah dicapai umumnya berpengaruh sangat baik terhadap prestasi berikutnya. Selain itu dengan adanya tes hasil belajar, siswa juga dapat mengetahui kelebihan dan kelemahan yang dimilikinya sehingga siswa dapat mempergunakan pengetahuannya untuk meningkatkan prestasinya.

Dari segi guru, dengan adanya tes hasil belajar, maka seorang guru juga dapat mengetahui kelemahan dan kelebihan dalam proses pembelajaran yang dilakukannya. Mengetahui kelebihan dan kekurangannya dalam proses pembelajaran akan menjadi motivasi bagi guru untuk menentukan usahausaha selanjutnya. Selain itu tes hasil belajar juga berfungsi dalam membantu guru untuk menilai kemampuan anak didiknya, mengetahui status anak didik dalam kelasnya, membantu guru dalam megelompokan siswa, membantu guru dalam memilih metode mengajarnya dan membantu guru dalam memberikan materi pelajaran tambahan dan remedial.

c. Dasar administratif: 1) Memberikan data untuk dapat menentukan status siswa di kelasnya; 2) Memberikan iktisar mengenai segala usaha yang dilakukan oleh sebuah lembaga pendidikan; dan 3) Merupakan inti laporan kemajuan belajar siswa terhadap orang tua atau walinya.

Sudjana (2005) menyatakan ada beberapa fungsi penilaian, yaitu: 1) merupakan alat untuk mengetahui tercapai atau tidaknya suatu tujuan instruksional yang telah ditetapkan. 2) umpan balik untuk perbaikan proses belajar mengajar. 3) sebagai pedoman untuk menyusun laporan belajar siswa kepada orang tuanya atau walinya.

Dari pendapat-pendapat di atas dapat disimpulkan bahwa penilaian berfungsi membantu guru untuk mengukur sampai dimana keberhasilannya mengajar dan mendidik siswa di kelas, membantu siswa untuk mengetahui statusnya dalam hal ini kemampuanya dalam memahami materi jika dibandingkan dengan teman-temannya, menjawab keingintahuan orang tua atau wali siswa mengenai kemampuan anaknya baik dari segi kognitif, afektif dan psikomotor. 
Sudjana (2005) mengemukakan tujuan dari penilaian hasil belajar sebagai berikut: 1) Mendeskripsikan kecakapan belajar siswa sehingga kelebihan dan kekurangannya dalam berbagai bidang studi atau mata pelajaran yang ditempuhnya diketahui. Degan pendeskripsian kecakapan tersebut diketahui juga tingkat kemampuan siswa jika dibanding dengan siswa lainnya. 2) Mengetahui keberhasilan proses kegiatan belajar mengajar di sekolah, yaitu tingkat keefektifannya dalam mengubah tingkah laku siswa ke arah tujuan pendidikan yang diharapkan. 3) Menentukan tindak lanjut hasil penilaian, dalam hal ini melaksanakan perbaikan dan penyempurnaan dalam program pendidikan dan pengajaran serta sistem pelaksanaannya. 4) Memberikan pertanggungjawaban dari pihak sekolah kepada pihak-pihak yang berkepentingan.

Ada beberapa faktor yang dapat mempengaruhi hasil belajar siswa yaitu: 1)faktor pada diri siswa diantaranya intelegensi, kecemasan (emosi), motivasi yang diberikan saat belajar, minat, sikap dan ketekunan dalam belajar, dan faktor fisik dan psikis. 2) faktor dari luar diri siswa seperti ukuran ruang kelas, suasana belajar dalam kelas (termasuk didalamnya guru), sarana dan prasarana dan sumber belajar yang tersedia.

Dalam mengumpulkan informasi mengenai kemajuan belajar peserta didik, yang terkait dengan aspek sikap, pengetahuan, dan keterampilan dapat 6 dilakukan melalui berbagai teknik penilaian. Ada 3 pengelolaan hasil belajar yaitu:

a. Pengolahan Nilai Aspek Sikap, diperoleh melalui penggunaan instrumen: (1) observasi; (2) Penilaian diri sendiri; (3) Penilaian antar teman; dan (4) Catatan harian guru. Tetapi dalam pengolahan nilai yang akan diisi dalam buku raport, penilaian diri sendiri dan penilaian antar teman hanya digunakan sebagai bahan untuk mengkonfirmasi. Sedangkan catatan harian guru digunakan untuk mengisi saran-saran pada buku rapor.

b. Pengolahan Nilai Aspek Pengetahuan, walaupun nilai aspek pengetahuan diolah secara kuantitatif, tetapi yang diisi dalam raport adalah deskripsi kualitatif. Deskripsi tersebut merupakan kalimat positif tentang apa yang menonjol yang berkaitan dengan kemampuan siswa dalam setiap mata pelajaran, dan usaha-usaha apa yang perlu untuk mencapai kompetensi yang telah ditetapkan. Oleh karena itu, sebelum melaksanakan ulangan harian, ujian tengah semester, dan ujian akhir semester perlu diperhatikan langkahlangkah sebagai berikut.

1) Menyusun kisi-kisi tes:

- Untuk ulangan harian kisi-kisi bersumber dari muatan mata pelajaran pada Kompetensi dasar dari aspek pengetahuan.

- Untuk UTS kisi-kisi bersumber dari materi mata pelajaran pada 
Kompetensi dasar dari aspek pengetahuan yang telah diberikan.

- Untuk UAS kisi-kisi bersumber dari materi mata pelajaran pada Kompetensi dasar dari aspek pengetahuan dalam satu semester.

2) Menyusun soal sesuai kisi-kisi

3) Melaksanakan ujian/tes

4) Menganalisis hasil ujian/tes bertujuan untuk mengetahui kelebihan dan kekurangan setiap siswa dari materi mata pelajaran dalam satu perangkat soal.

Hasil analisis ini digunakan sebagai dasar untuk melakukan program remedial dan pengayaan. Demikian juga untuk UTS dan UAS, dengan menggunakan langkah yang sama tetapi dengan cakupan KD yang lebih luas.

Dalam mengisi deskripsi pada raport harus mempertimbangkan kecenderungan anak (kelebihan dan kekurangan mengenai muatan mata pelajaran yang terangkum dalam ulangan harian, Ujian tengah semester, dan Ujian akhir semester). Untuk menghitung nilai capaian kompetensi siswa secara kuantitatif dilakukan untuk dapat mengetahui kriteria ketuntasan minimal (KKM) yang dijadikan dasar pertimbangan dalam melakukan program remedial.

Untuk menghitung nilai capaian kompetensi siswa secara kuantitatif, dilakukan dengan memperhatikan langkahlangkah sebagai berikut:

1. Menghitung nilai harian $(\mathrm{NH})$. Nilai harian merupakan nilai yang diperoleh dari hasil ulangan harian. Nilai harian dapat diperoleh dengan cara tes tulis, tes lisan, dan penugasan yang dilaksanakan pada setiap akhir satu sub-tema pembelajaran sesuai dengan kebutuhan guru.

2. Menghitung nilai Ujuan Tengah Semester (UTS). Nilai UTS adalah nilai yang diperoleh dari hasil tes tulis yang dilaksanakan pada tengah semester. Materi Ulangan Tengah Semester mencakup seluruh kompetensi yang telah diberikan sampai dengan saat pelaksanaan UTS.

3. Menghitung nilai Ujian Akhir Semester (UAS) . Nilai UAS adalah nilai yang diperoleh dari hasil tes yang dilaksanakan di akhir semester. Materi UAS mencakup seluruh materi capaian kompetensi pada satu semester yang berjalan.

4. Penghitungan Nilai Pengetahuan diperoleh dari rata-rata Nilai Harian (NH), Ujian Tengah Semester (UTS), dan nilai Ujian Akhir Semester (UAS).

5. Penilaian raport untuk aspek pengetahuan menggunakan penilaian kuantitatif.

c. Pengolahan nilai Keterampilan, diperoleh lewat penilaian kinerja yang terdiri atas:

1. Nilai Kinerja

2. Nilai produk atau hasil 


\section{Nilai Portofolio}

\section{Penilaian Praktik}

Penilaian memiliki beberapa tahapan yang akhirnya dapat dijadikan suatu patokan untuk membuat suatu hasil nilai siswa, yang nantinya akan menciptakan suatu bahan laporan hasil belajar siswa. Dengan adanya laporan hasil belajar siswa, pihak sekolah dalam hal ini dapat menjawab keingintahuan orang tua seperti:

a. Bagaimana peserta didik belajar di sekolah secara akademik, fisik, sosial maupun emosional

b. Sejauh mana keterlibatan anaknya dalam kegiatan di sekolah

c. Kemampuan yang diraih anaknya selama kurun waktu belajar

d. Apa yang harus dilakukan orang tua dalam membantu mengembangkan potensi anaknya lebih lanjut.

Laporan Hasil Belajar Siswa merupakan tugas akhir dari seluruh aktivitas guru sebagai pendidik, pelatih dan pembimbing di sekolah. Dalam laporan hasil belajar siswa terdapat beberapa langkah yang harus dilakukan seorang guru agar penilaian yang dilakukan sesuai dengan kriteria yang ditentukan oleh instansi sekolah, salah satunya dengan menentukan Kriteria Ketuntasan Minimal (KKM).

KKM merupakan dasar penentuan setiap kelas dalam memenuhi standar kompetensi yang diharapkan. Nilai KKM ditetapkan pada awal tahun pelajaran untuk setiap mata pelajaran, dan dievaluasi ketercapaiannya pada setiap semester, sebelum akhirnya dapat dirumuskan sebagai laporan hasil belajar siswa. Dalam hal ini KKM sebagai bentuk dasar seorang pendidik atau guru menentukan kenaikan kelas atau penjurusan.

$$
\text { Langkah-langkah dari KKM }
$$
meliputi:

a. Penetapan nilai KKM dilakukan melalui analisis ketuntasan belajar minimal pada setiap indikator. Indikator merupakan aspek yang akan diukur, misalnya minat belajar, motivasi belajar, disiplin, kerjasama, dsb.

b. KKM didapat dengan mencari rata-rata semua indikator pada kriteria dasar yang terkait.

c. KKM standar kompetensi merupakan rata-rata KKM kompetensi dasar yang terdapat pada setiap standar kompetensi.

d. Nilai KKM mata pelajaran merupakan rata-rata ketuntasan belajar bagi setiap standar kompetensi pada tingkat kelas bersangkutan.

Dasar penyampaian laporan hasil belajar siswa sebagai berikut:

a. Rapor adalah laporan kemajuan belajar siswa dalam kurun waktu satu semester, yang akan dilaporkan guru pada orang tua siswa.

b. Berisi informasi tentang pencapaian kompetensi yang telah ditetapkan dalam kurikulum.

c. Sekolah dapat membuat model raport yang dikehendaki, dengan syarat 
komunikatif dan dapat menggambarkan pencapaian kompetensi.

d. Model yang ada harus merupakan contoh yang dapat dimodifikasi/ diadopsi oleh sekolah.

e. Nilai yang dituliskan dalam rapor merupakan gambaran dari kemampuan siswa.

Rapor siswa sangat penting dan mempunyai fungsi sebagai:

a. Laporan hasil belajar siswa selama mengikuti kegiatan pembelajaran di sekolah.

b. Informasi pencapaian kompetensi yang telah ditetapkan dalam kurikulum yang ada di sekolah.

\section{Kemajuan Teknologi Dalam Dunia Pendidikan dan Contohnya Mailing (Mail Merge)}

Microsoft word adalah program pengolah kata yang sangat populer dan yang paling banyak digunakan para pemakai komputer. Lengkapnya fasilitas, kemudahan, kesederhanaan operasinya dan kemampuan untuk bertukar data dengan aplikasi windows yang lain adalah sebagian alas an orang banyak menggunakan program ini.

Semua jenis pekerjaan yang berhubungan dengan tulis menulis, mulai dari penulisan surat, laporan, makalah hingga desktop publishing dapat dikerjakan dengan menggunakan Microsoft word.

Aplikasi Word pada Microsoft Office merupakan perangkat lunak untuk peng- olahan kata (word processor) andalan Microsoft. Pertama diterbitkan pada 1983 dengan nama Multi-Tool Word untuk Xenix, versi-versi lain yang kemudian dikembangkan menjadi berbagai sistem operasi, misalnya DOS (1983), Apple Macintosh (1984), SCO UNIX, OS/2, dan Microsoft Windows (1989). Microsoft office word adalah perubahan dari Microsoft office system 2003 dan 2007 (Madcoms, 2010).

Microsoft Excel (MS-Excel) merupakan program aplikasi spreadsheet (lembar kerja elektronik) canggih yang sangat banyak digunakan dan populer saat ini. Excel sangat membantu kita dalam hal menghitung, memproyeksikan, menganalisa dan dapat menyajikan data dalam bentuk tabel dengan berbagai jenis tabel yang disediakannya, mulai dari bentuk Bar, Grafik, diagram lingkaran, diagram garis dan masih banyak lagi. Excel 2010 merupakan pengembangan dari excel versi sebelumnya yang lebih ditingkatkan fungsinya dan dipusatkan agar spread sheet ini lebih mudah dipakai, lebih fleksibel, lebih mudah diintegrasikan dengan program office lainnya dan juga versi ini dapat langsung dihubungkan dengan internet.

Mail Merge atau surat masal merupakan sebuah fasilitas yang selalu ada pada aplikasi Word untuk mengirimkan kepada beberapa orang sekaligus dari satu sumber surat. (Kusrianto, 2014) Secara teknis, dibutuhkan dua buah file yaitu file word dan word atau word dan exel untuk mengolahnya, yang pertama adalah isi surat 
sementara yang lainnya adalah data kepada surat tersebut dikirimkan, kemudian pada proses pengiriman, kedua file tersebut digabungkan.

Fasilitas Mail Merge memiliki beberapa kegunaan. Salah satunya adalah untuk menggabungkan data-data dokumen pada Word dengan data dokumen yang ada pada Excel. Maksudnya adalah, data-data yang ditulis dalam bentuk list/kolom pada Excel akan berfungsi sebagai sumber data bagi para "penerima surat" (Recipients) atau database-nya, yang nanti akan dituliskan pada dokumen Word sebagai alamat surat, dimana tulisan tersebut berfungsi sebagai "format surat"-nya(Rifani, 2012).

\section{Pelatihan}

Pembuatan

Raport

\section{Menggunakan Mailing}

Pada pelatihan kali ini, para guru dibimbing mengenai cara membuat Mail Merge. Mail Merge sendiri merupakan sub program dari word yang membuat kita lebih leluasa dalam mengirimkan surat dengan jumlah penerima tak terbatas contohnya dokumen raport. Menggunakan Microsoft Excel sebagai suatu program yang juga dipadankan dengan Microsoft word untuk menghubungkan surat tersebut dengan data yang ada pada Excel. Maka kita tidak perlu lagi menulis satu persatu nama dan alamat yang dituju serta nilai-nilai raport namun cukup meng-input saja pada program Excel.

Dalam proses pelatihan, pertama dibuka program MS Word dan MS Excel. 10
Setelah itu ditulis surat dalam bentuk laporan hasil belajar siswa (Raport) pada program Word. Setelah selesai masuk pada program Excel, di input data penerima dan alamat dan nilai dari masing-masing siswa per mata pelajaran. Setelah selesai kemudian file disimpan. Masuk kembali pada program Word, kemudian surat tersebut dihubungkan dengan data nama penerima dan alamat dengan memilih pilihan Mail merge pada layar atas dan dengan memanfaatkan pilihan yang ada.

Caranya adalah para guru membuka Microsoft word dan mengetikan dokumen master (Format Raport yang akan dibuat) selanjutnya membuat data base yaitu nilainilai setiap siswa dari semua mata pelajaran. Selanjutnya pada langkah mengabungkan dokumen word dan excel untuk memproduksi raport atau sertifikat dengan cara meng-klik start mailing, disini terdapat pilihan apakah bentuknya surat, amplop atau dokumen word biasa yang akan dibuat, namun karena pembahasan ini dalam bentuk surat jadi yang dipilih leters dan diklik. Selanjutnya pilih "select recipients" dan sorot klik "use exiting list". Daftar (list) yang dimaksud disini adalah data nama dan alamat serta nilai yang kita buat dan yang sudah simpan tadi, carilah file Excel yang disimpan tersebut, maka akan keluar pilihan sheet atau halaman yang sudah dibuat, karena data telah diolah dalam halaman (sheet) pertama, sorot "sheet 1". Maka data exel yang telah dibuat tadi akan tersambung. 
Selanjutnya klik Edit Recipient List untuk menentukan siapa penerima atau data siapa yang akan diproses dengan mencentang pada kolom nama yang tersedia. Pada jendela Edit Recipient List juga dapat dilihat kembali alamat merge field yang akan diinput nanti. Untuk menampilkannya dalam surat tadi sorot kemudian klik "insert merge field", atau ketika kita perintahkan untuk memilih menampilkan data apa yang telah di input.

Kemudian diletakkanlah kursor pada nama atau alamat dan nilai yang dikosongkan, dan pilih Field sesuai dengan kursor tadi. Selanjutnya setelah selesai menginsert dan kita ingin memeriksa kebenaran atau ketepatan letak data, maka klik preview results dan dilanjutkan dengan mengklik tanda panah kiri kanan atau Find recipient. Jika telah diperiksa dan benar langkah terakhir yaitu print namun agar dokumentasinya jelas, kita akhiri mailing dengan mengklik Finish \& Merge dan pilih edit individual. setelah langkah tersebut maka akan terbentuk file yang baru yang terdiri dari tiap lembaran yang kita inginkan dan diakhiri dengan menyimpan berkas pada word dengan mengkilk save as atau dengan menekan keyboard ctrl+S dan menuliskan nama file sesuai dengan yang kita inginkan dan mudah diingat.

Untuk mencetak hasil mail merge yang sudah dibuat dokumen juga caranya sedikit berbeda. Jika ingin mencetak dokumen word yang tidak di mail merge biasanya kita hanya menuliskan halaman yang akan dicetak pada kolom halaman dengan angka 1 atau 1-10. Namun untuk dokumen hasil mail merge, jika dokumen master terdiri dari dua lembar maka untuk mengeprint lembar satu untuk penerima pertama sampai sepuluh pada kolom halaman dituliskan p1s1-p1s10. Dan jika akan mencetak lembar kedua untuk penerima pertama sampai sepuluh pada kolom halaman dituliskan p2s1-p2s10.

\section{Pembahasan}

Dari kegiatan sosialisasi dan pelatihan mailing merge (Mailing), maka dapat disimpulkan hal-hal sebagai berikut: Program MS Word dan MS Excel adalah program satu paket yang dapat saling terhubung, salah satu hubungannya adalah penyatuan data Excel dan dokumen dari Word dalam bentuk Mail Merge. Fungsi Mailing atau Mail Merge pada Word adalah membuat surat massal, artinya dapat mengirimkan kebanyak penerima dan rinciannya. Mengunakan Mailing atau Mail Merge memiliki keuntungan seperti tidak perlu membuat banyak-banyak surat dengan tujuan dan rincian dimasing-masing surat tersebut, contohnya membuat raport.

Dengan memanfaatkan fungsi Mailing atau mail merge salah satu tugas guru yaitu pengelolahan dan penulisan raport yang memakan waktu beberapa hari menjadi lebih mudah dan bisa diselesaikan dalam satu atau dua jam dengan hasil yang maksimal. Fungsi Mailing juga dapat dimanfaatkan guru dalam membuat surat 
undangan rapat orang tua, surat pemberitahuan yang masal dan sertifikatsertifikat dalam waktu yang relative singkat dibandingkan dengan membuat dokumen tersebut satu persatu.

Dalam melaksanakan pelatihan ini ditemukan kendala yaitu pengetahuan tentang Microsoft office para guru yang kurang membuat pelatihan ini menjadi agak sulit. Pendektan yang dilakukan untuk memecahkan masalah ini adalah mengkolaborasikan metode simulasi, tutor dan praktikum. Walaupun menemukan kendala yang berat namun pelatihan yang diberikan dapat memberikan pengetahuan bagi para guru.

Hasil pelatihan ini akan memberi dampak yang berarti jika para guru memanfaatkannya dalam menyelesaikan tugas dan tanggung jawab mereka. Dan tentunya dibutuhkan dukungan dari para pemimpin untuk memberikan kebijakan tentang pemanfaatan teknologi dalam dunia pendidikan terlebih khusus dalam pendidikan dasar.

\section{KESIMPULAN}

Hasil yang dicapai melalui kegiatan pengabdian ini adalah para guru memperoleh pengetahuan dan pengalaman tentang cara memanfaatkan teknologi dalam dunia pendidikan lebih khusus dalam pembuatan raport dengan menu mail merge (Mailing).

\section{KEPUSTAKAAN}

Budi Permana. 2010. Microsoft Excel 2000. Elex Media Komputindo . Jakarta.

Kusrianto Adi. 2014. Aplikasi excel Untuk Guru. Elex Media Komputindo . Jakarta.

Madcoms Madiun. 2015. 100 Tip \& Trik Microsoft Word 2013. Andi. Yogyakarta.

Sudjana, N.2005. Penilaian Hasil Proses Belajar Mengajar. PT Remaja Rosdakarya. Bandung.

Suryabrata, S.2001. Psikologi Pendidikan. Universitas Gadjah Mada. Yogyakarta 